\title{
THE MARITAL DEDUCTION: QUALIFICATION OF THE SURVIVING SPOUSE'S LIFE ESTATE
}

Section 2056 of the federal estate tax permits a marital deduction for the value of a life estate created in the surviving spouse provided the life estate includes a power of appointment ${ }^{1}$ that is exercisable by the surviving spouse alone and "in all events" in her favor or in favor of her estate. Taxpayers have sought to take advantage of this deduction by giving the surviving spouse a life estate with a power to consume the property or invade the corpus of a trust. Whether such powers will qualify the life estate for the marital deduction has been the subject of considerable litigation.

In the recent case of Thomas J. Semmes ${ }^{2}$ the deceased created a testamentary trust in favor of his widow for life, remainder, if any, to his children. His widow was given sole discretion in the management of the trust and an unrestricted power to invade the corpus for her own benefit. ${ }^{3}$ The decedent's executor contended that, under Tennessee law, the power to invade the corpus made the surviving spouse unconditional owner of the property and thus qualified her life estate for the marital deduction. ${ }^{4}$ The Tax Court, however, strictly construed section 2056 of the Code and held that her power to invade the corpus failed to qualify under Tennessee law as a power to appoint the entire interest in

${ }^{1}$ INT. Rev. Code of 1954, \$2056(b) (5). See generally Lowndes \& KRAMER, Federal Estate and Gift Taxes, 79I (1956); Alexander, The Marital Deduction, 20 Oнiо ST. L.J. 99 (1959).

232 T.C. No. I 9 (Sept. 22, 1959).

${ }^{3}$ "The will provided as follows: 'My wife shall have sole power of management and control of said trust property, and shall have sole power of management and control of said trust property, and shall receive for her own benefit during her own lifetime all the dividends and other income derived from said trust, and she shall have the right to sell said stock and reinvest the proceeds of sale, at her discretion, provided that she must sell the whole of said stock when she elects to sell, and not retain any of this block of 255 shares. Any reinvestment she may make of the proceeds of the sale, shall be impressed with the same trust herein provided for. She shall have the sole right to vote said stock at any stockholders meeting of the Semmes Bag Company, Inc. My wife shall have the right to encroach upon the principal or corpus of said trust property for her own benefit, at any time she sees fit, without accounting to my children, or their representatives." " The remainder was left to the children of the decedent; if none should survive, then to the wife absolutely. Thomas J. Semmes, supra note 2, at I.

"The "unconditional owner" approach to the problem of what is an unlimited power is discussed in Ralph G. May, 32 T.C. No. 38 (May 26, 1959). Treas. Reg. I05, $\$ 81.47(\mathrm{a})$, contained this test. 
the trust: "Nothing in the will indicates an intention that the widow could at any time dispose of the property by gift or appoint the corpus to herself as unqualified owner."

Similar results have been reached in several cases in which the powers of the surviving spouse clearly failed to qualify her life estate for the marital deduction. ${ }^{6}$ These cases involved testamentary provisions to the effect that the surviving spouse could consume the property for her comfort, support, maintenance, or general welfare, or for some combination of these reasons. Such limited powers clearly fail to satisfy the requirements of section 2056.7 Similarly, a power to consume the property up to a certain sum is too limited to qualify. ${ }^{8}$ Less obvious provisions that also fail to qualify the estate for the deduction allow the surviving spouse to invade the corpus "for her happiness," or grant her the power to "sell, deed, or transfer"10 her interest. In these and other cases involving unequivocally worded provisions to the effect that the power to consume or invade is to be exercised as the spouse sees $\mathrm{fit}^{11}$ or with "uncontrolled discretion,"12 the courts have held that, because local trust law required such powers to be exercised "in good faith" or "honestly and fairly" for the protection of the remaindermen, such fiduciary limitations were sufficient to disqualify the estate for the mari-

5 32 T.C. No. II9, at 4. "In Black v. Pettigrew, 38 Tenn. App. I, 270 S.W.2d 196, the court construed 'to have and to enjoy in any way she may deem proper' and in Jones v. McMurrey, 25 Tenn. App. 47, 150 S.W.2d 713, the words to be used as she sees fit.' In both cases such words, in the life tenants' grants, followed by gifts over, were held to give each life tenant something less than an unqualified right to dispose of the corpus." 32 T.C. No. I 19 , at 4 .

"E.W. Noble, 3 I T.C. No. 86 (Jan. 28, 1959) ("maintenance, support and comfort"); Estate of Tarver v. Commissioner, 255 F.2d 913 (4th Cir. 1958) (her support and support of the children in her discretion); Elwood Comer, 31 T.C. No. I23 (March 25, 1959) ("maintenance, comfort and general welfare"); Michael Malamid, 22 T.C. 966 (1954) ("for the way of life to which she and I have been accustomed").

Treas. Reg. $\$ 20.2056(\mathrm{~b})-5$ (a) (3) (1958).

${ }^{5}$ Willard Cummings, 31 T.C. No. 97 (Feb. I 1, 1959) (power to invade up to $\$ 5000$ per year).

${ }^{\circ}$ Ralph G. May, 32 T.C. No. $3^{8}$ (May 26, 1959) ("comfort, happiness and wellbeing"). Under New York law the power is not unlimited since only a "good faith" exercise of the power would be allowed. Matteson v. United States, 147 F. Supp. 535 (N.D.N.Y., I956). The New York law on the subject is summarized in Edward F. Pipe, 23 T.C. 99 (r 954); Pipe's Estate v. Commissioner, $24 \times$ F.zd 2 ro (2d Cir. 1957); Note, 7 I Harv. L. Rev. 381 (1957); Note, 57 Colum. L. Rev. 893 (1957).

${ }^{10}$ Harriet C. Evilsizor, 27 T.C. 7 10 (1957) ("sell, deed or transfer any or all ... property").

${ }_{11}$ Commissioner v. Ellis' Estate, 252 F.2d rog (3d Cir. 1958).

22 Pipe's Estate v. Commissioner, 24I F.2d 2 10 (2d Cir. I957). 
tal deduction. ${ }^{13}$ One court has even held that the mere existence of a remainder limits the exercise of the power. ${ }^{14}$

In disallowing the marital deduction, the courts have thus premised their decisions upon the ground that the local trust or property law imposed limitations upon the exercise of the power. ${ }^{15}$ In at least one state, for example, the addition of a power of sale to a life estate does not enlarge that estate to a fee simple. In a case in which the widow held the power to "sell, deed, or transfer," this rule of property was held to be a sufficient limitation upon the exercise of the power to disqualify the estate for the deduction. ${ }^{16}$ The validity of such a construction is questionable. Following enactment of the I954 Code, some authors, supported by the regulations, ${ }^{17}$ contended that a nontechnical power to appoint would qualify the life estate for the marital deduction even though the power was not called a power of appointment by local property law. ${ }^{18}$ Moreover, a Senate committee report implied that a nontechnical power was intended when it stated that a power which in substance and effect was a power to appoint would be sufficient "regardless of . . . local property-law connotations." ${ }^{\prime \prime}$ This is the same test applied to section 204I of the Code, which pertains to the taxation of powers of appointment. ${ }^{20}$

The Regulations do not provide an adequate guide in this area. In setting forth the requirement that a power of appointment must be exercisable in favor of the surviving spouse, the Regulations employ as an example an "unlimited power to invade." Later, the same section of the Regulations sets forth the requirement that the surviving spouse's unlimited power to consume or invade must be accompanied by the

\footnotetext{
${ }^{13}$ Commissioner v. Ellis' Estate, 252 F.2d 109 (3d Cir. 1958); Ralph G. May, 32 T.C. No. 38 (May 26, 1959).

${ }^{14}$ Delia Crawford McGehee, 28 T.C. 412 (1957).

${ }^{15}$ Commissioner v. Ellis' Estate, 252 F.2d 109 (3d Cir. 1958); Estate of Tarver v. Commissioner, 255 F.2d 913 (4th Cir. 1958); Pipe's Estate v. Commissioner, 241 F.2d 2 ro (2d Cir. 1957); Ralph G. May, 32 T.C. No. 38 (May 26, 1959); Elwood Comer, 31 T.C. No. 123 (March 25, 1959); E. W. Noble, 31 T.C. No. 86 (Jan. 28, 1959); Wallace S. Howell, 28 T.C. I1 93 (1957); Harriet C. Evilsizor, 27 T.C. 710 (1957); Delia Crawford McGehee, 28 T.C. 412 (1957); Michael Malamid, 22 T.C. 966 (1954).

${ }_{10}$ Harriet C. Evilsizor, supra note ${ }_{5}$, citing Tax Commission v. Oswald, 109 Ohio St. 36, 141 N.E. 678 (1923).

17 Treas. Reg. 105, $\$ 81.47$ (a) (c) (i) 1942.

${ }^{18}$ Lowndes \& KRAMER, op. cit. supra note 1 , at 412.

${ }^{10}$ S. REP. No. 1013, 8oth Cong., 2d Sess. I7 (1948).

20 Treas. Reg. $\$ 20.2041$ (1) (b) (1958).

${ }^{2 x}$ Treas. Reg. $\$ 20.2056(\mathrm{~b})-5(\mathrm{~g})(\mathrm{I})(\mathrm{i})$ (1958).
} 
power to dispose of the property by gift "(whether or not she has the power to dispose of it by will)."22 This statement would seem to indicate that remainders were anticipated and approved.

The fact that local law labels the power a power to invade or consume rather than a power to appoint should not be fatal to the marital deduction. Language should not be controlling. The Senate committee report on section 2056 indicated that a power which in "substance and effect" was a power to appoint would be sufficient to qualify for the marital deduction regardless of the nomenclature used in creating the power. $^{23}$ At present, the Regulations ${ }^{24}$ and dicta in a few cases $^{25}$ provide that an unlimited power to invade will qualify the appointive property for the marital deduction. In application, however, the courts have been reluctant to find that such a power really existed. ${ }^{26}$

In view of the committee report and the Regulations, it would seem that, as a matter of construction, a reversal in the trend of judicial authority is warranted. It would certainly be desirable, if for simplicity alone, to employ a consistent definition of power of appointment throughout the Code. Moreover, to adopt the broad definition of power of appointment in section 204I would be more equitable in that a single tax rather than a double tax would result. The property remains taxable to the estate of the surviving spouse under section 204I; if the power to consume or invade is treated as qualifying for the marital deduction, then the payment of the tax will merely be postponed until the death of the surviving spouse, which is the normal operation of the marital deduction.

Presently, however, the courts are unwilling to adopt the definition of a power of appointment in section 204r of the Code because of what

\footnotetext{
${ }^{29}$ Treas. Reg. $\$ 20.2056(\mathrm{~b})-5(\mathrm{~g})(3)$ (1958).

${ }^{23}$ S. REP. No. Ior 3 , soth Cong., $2 d$ Sess. ${ }_{7}$ (1948). The provision first appeared with regard to the Revenue Act of 1948,62 Stat. I Io.

${ }_{24}$ Treas. Reg. $\& 20.2056(\mathrm{~b})-5(\mathrm{~g})(3)$ (1958).

${ }^{25}$ Commissioner v. Ellis' Estate, 252 F.2d rog (3d Cir. 1958); Stallworth's Estate v. Commissioner, 260 F.2d 760 (5th Cir. 1958); Pipe's Estate v. Commissioner, 24r F.2d 210 (2d Cir. 1957).

${ }^{20}$ Commissioner v. Ellis' Estate, supra note 25; Pipe's Estate v. Commissioner, suppra note 25; Ralph G. May, 32 T.C. No. ${ }_{3} 8$ (May 26, r 959); Delia Crawford McGehee, 28 T.C. 412 (1957).

In the Stallworth case, supra note 25 , the court allowed the marital deduction and said that an unlimited power to invade or consume existed. However, the case is of doubtful precedent in view of the fact that the will also contained an express power to appoint as set forth in section 204r, which would have been sufficient to qualify the estate for the marital deduction quite independently of the power to invade or consume.
} 
they regard as the obvious import of the words of the statute. ${ }^{27}$ As a judicial change of construction seems unlikely, the statute should be amended to provide unequivocally that the definition of a power of appointment contained in section 204I shall also apply to section 2056. Such an amendment would resolve the inconsistency in the two sections, obviate any uncertainty now posed by the cases and the Regulations, and provide the draftsman with a definite standard.

With the law in its present state, the draftsman is best advised that, although an unlimited power to invade the corpus of a trust, or to consume the principal of an estate, will qualify for the marital deduction, the courts have followed local law to say that the power in any particular case is not really unlimited. Accordingly, the power to appoint should be expressly granted to the surviving spouse if the marital deduction is desired. ${ }^{28}$

\footnotetext{
${ }^{27}$ Pipe's Estate v. Commissioner, 24 I F.2d 2 I0 (2d Cir. r957).

${ }^{28}$ For alternatives to the use of the power of appointment, see LowNDEs \& KRAMER, op. cit. supra note 1 , at 893 ; Alexander, supra note I, at I I .
} 